\title{
The Dynamics of Mounds-Clusters in the Mouhoun Bend (Burkina Faso)
}

\author{
Augustin FC Holl* \\ Department of Anthropology, Africa Research Center, Xiamen University, PR China
}

*Corresponding author: Augustin FC Holl, Department of Anthropology, Africa Research Center, Xiamen University, Xiamen, Fujian, PR China

\begin{abstract}
Mounds are human made accumulations of settlements debris of varying size and shapes, found in different parts of the world. In West Africa, they tend to be located in relatively flat lands, at low elevations, in wetlands, marshlands or flood plains. Some are large single mound sites. Others are made of groups of scattered or clustered mounds - mound-clusters -, spread over varying surface extent. The dynamics of such settlement systems is still poorly understood partly because of inadequate field methodology. Ethno-historical and ethnographic data from West Africa recent past are relied upon to suggest some of the key processes behind mounds clustering: ethnicity, craft affiliations, or a combination of both. The Mouhoun Bend Archaeological Project (MOBAP 19972000) was designed to address this issue. The field methodology was articulated on testing all mounds parts of the mound-clusters under investigation. Two mound-clustering strategies were identified:

a. Tight-clustering resulting in the formation of a large "single mound site", and

b. Loose-clustering with scattered individual mounds of different size and shape.

Residential and craft requirements combined differentially in the 2000 years Mouhoun Bend settlement history, have generated the settlement patterns investigated in the study area. The ethnicity component of the identified dynamics - that is plausible - could not be tracked with the current methodology and is accordingly undecidable.
\end{abstract}

\section{Introduction}

The Mouhoun bend was settled by iron-using communities in the first millennium BCE (Figure 1, Table 1). The climate was wetter [1]. The Sudanian savanna and the Mouhoun River offered a diversified resources mix that allowed for the stabilization and growth of these mixed farming fishing populations. Their settlements consisted of multi-mound complexes - moundclusters. The sample of sites excavated within the Mouhoun Bend Archaeological Project (MOBAP 1997 - 2000) offers an entry into the dynamics of this kind of settlement that developed and spread in the study area for a little more than 2000 years, from ca. 700/500 BCE to 1650 CE (Figure 1, Table 1).

Table 1: Radiocarbon dates from the Mouhoun Bend Archaeological Project.

\begin{tabular}{|c|c|c|c|c|c|}
\hline ISGS NO & SAMPLE & C-14 AGE (RCYBP) & C-13 (VS PDB) & Cal BC/AD (1 sigma) & Cal BC/AD (2 sigma) \\
\hline \multicolumn{6}{|c|}{ Kerebe-Sira-Tomo } \\
\hline \multicolumn{6}{|c|}{ KST-1 } \\
\hline $1-3941$ & KST-1 $(20 \mathrm{~cm})$ & $2050+/-70$ & -9.7 & $167 \mathrm{BC}-47 \mathrm{AD}$ & $348 \mathrm{BC}-117 \mathrm{AD}$ \\
\hline \multicolumn{6}{|c|}{ KST-2 } \\
\hline $2-3937$ & KST-2 $(20 \mathrm{~cm})$ & $930+/-70$ & -25.3 & $1021-1209$ AD & $983-1260$ AD \\
\hline $3-3932$ & $\mathrm{KST}-2(60 \mathrm{~cm})$ & $880+/-70$ & -25.7 & $1037-1241$ AD & $1018-1281$ AD \\
\hline $4-3936$ & KST-2 $(140 \mathrm{~cm})$ & $1660+/-70$ & -25.5 & $261-434 \mathrm{AD}$ & $237-556 \mathrm{AD}$ \\
\hline
\end{tabular}




\begin{tabular}{|c|c|c|c|c|c|}
\hline \multicolumn{6}{|c|}{ KST-3 } \\
\hline $5-4302$ & KST-3 $(20-40 \mathrm{~cm}) 800+/-70$ & -25 & $1165-1283 \mathrm{AD}$ & & $1039-1376 \mathrm{AD}$ \\
\hline $6-4310$ & KST-3 (40-60) & $770+/-70$ & -24.7 & $1215-1291 \mathrm{AD}$ & $1070-1385 \mathrm{AD}$ \\
\hline $7-4311$ & KST-3 (60-80) & $800+/-70$ & -25.5 & $1165-1283 \mathrm{AD}$ & $1039-1376 \mathrm{AD}$ \\
\hline $8-4321$ & KST-3 (80-100) & $770+/-70$ & -25.7 & $1215-1291 \mathrm{AD}$ & $1070-1385 \mathrm{AD}$ \\
\hline $9-4319$ & KST-3 (100-120) & $790+/-70$ & -26.6 & $1191-1284$ AD & $1042-1379 \mathrm{AD}$ \\
\hline \multicolumn{6}{|c|}{ KST-4 } \\
\hline $10-4340$ & KST-4 (0-20) & $710+/-70$ & -25.1 & $1262-1382 \mathrm{AD}$ & $1195-1401 \mathrm{AD}$ \\
\hline $11-4343$ & KST-4 (40) & $550+/-70$ & -26.2 & $1313-1435 \mathrm{AD}$ & $1292-1453 \mathrm{AD}$ \\
\hline $12-4320$ & KST-4 (50) & $660+/-70$ & -24.6 & $1282-1396 \mathrm{AD}$ & $1244-1418 \mathrm{AD}$ \\
\hline 13 - LLNL & KST-4 (40-60) & $1830+/-50$ & & $123-235 \mathrm{AD}$ & $67-291 \quad A D * 1$ \\
\hline $14-4341$ & KST-4 (60) & $720+/-70$ & -26.8 & $1259-1379 \mathrm{AD}$ & $1191-1399 \mathrm{AD}$ \\
\hline $15-4344$ & KST-4 (75-80) & $790+/-70$ & -25.2 & $1191-1284 \mathrm{AD}$ & $1042-1379 \mathrm{AD}$ \\
\hline $16-4345$ & KST-4 (100) & $720+/-70$ & -24.7 & $1259-1379 \mathrm{AD}$ & $1191-1399 \mathrm{AD}$ \\
\hline \multicolumn{6}{|c|}{ KST-5 } \\
\hline $17-4346$ & KST-5(0-20) & $810+/-70$ & -25.4 & $1163-1281 \mathrm{AD}$ & $1037-1298 \mathrm{AD}$ \\
\hline $18-4347$ & KST-5(40-60) & $850+/-70$ & -25.5 & $1061-1263 \mathrm{AD}$ & $1022-1288 \mathrm{AD}$ \\
\hline $19-4348$ & KST-5(60-80) & $840+/-70$ & -25.5 & $1070-1274 \mathrm{AD}$ & $1024-1291 \mathrm{AD}$ \\
\hline \multicolumn{6}{|c|}{ Tora Sira Tomo } \\
\hline \multicolumn{6}{|c|}{ TST 1} \\
\hline $20-4349$ & TST-1(50) & $2360+/-70$ & -26.7 & $501-386 \mathrm{BC}$ & $761-212$ BC \\
\hline \multicolumn{6}{|c|}{ TST 3} \\
\hline $21-3927$ & TST-3 E (20-40) & $460+/-70$ & -22.5 & $1412-1477 \mathrm{AD}$ & $1326-1631 \mathrm{AD}$ \\
\hline $22-3931$ & TST-3 E (80-100) & $780+/-70$ & -26.4 & $1211-1287 \mathrm{AD}$ & $1059-1382 \mathrm{AD}$ \\
\hline $23-3928$ & TST-3 E(120-140) & $710+/-70$ & -25.8 & $1262-1382 \mathrm{AD}$ & $1195-1401 \mathrm{AD}$ \\
\hline $24-4586$ & TST-3 W(20-40) & $790+/-70$ & -24.8 & $1191-1284 \mathrm{AD}$ & $1042-1379 \mathrm{AD}$ \\
\hline 25 - LLNL & TST-3 W(20-40) & $740+/-40$ & - & $1212-1300 \mathrm{AD}$ & $1220-1380 \mathrm{AD}^{*} 2$ \\
\hline $26-4587$ & TST-3 W(40-60) & $740+/-70$ & -24.6 & $1223-1298 \mathrm{AD}$ & $1163-1393$ AD \\
\hline $27-4588$ & TST-3 W(60-80) & $880+/-70$ & -25.5 & $1037-1241 \mathrm{AD}$ & $1018-1281 \mathrm{AD}$ \\
\hline $29-4585$ & TST-3 W(100) & $960+/-70$ & -25.4 & $1003-1162 \mathrm{AD}$ & $904-1222 \mathrm{AD}$ \\
\hline $30-4590$ & TST-3 W(120) & $980+/-70$ & -24.9 & $997-1158 \mathrm{AD}$ & $899-1216 \mathrm{AD}$ \\
\hline \multicolumn{6}{|c|}{ TST 4} \\
\hline $31-4591$ & TST-4 (30) & $570+/-70$ & -25.7 & $1302-1426 \mathrm{AD}$ & $1286-1445 \mathrm{AD}$ \\
\hline \multicolumn{6}{|c|}{ TST 5} \\
\hline $32-4350$ & TST-5 (20-40) & $400+/-70$ & -24.8 & $1436-1627 \mathrm{AD}$ & $1408-1649 \mathrm{AD}$ \\
\hline $33-4356$ & TST-5 (80) & $440+/-70$ & -25.1 & $1420-1486 \mathrm{AD}$ & $1331-1637 \mathrm{AD}$ \\
\hline $34-4357$ & TST-5(80-100) & $560+/-70$ & -24.6 & $1304-1431 \mathrm{AD}$ & $1289-1449 \mathrm{AD}$ \\
\hline \multicolumn{6}{|c|}{ TST 6} \\
\hline $35-4358$ & TST-6 (40-60) & $630+/-90$ & -24.7 & $1284-1409 \mathrm{AD}$ & $1223-1441 \mathrm{AD}$ \\
\hline $36-4361$ & TST-6 $(80-100)$ & $770+/-70$ & -24.9 & $1215-1291 \mathrm{AD}$ & $1070-1385 \mathrm{AD}$ \\
\hline $37-4360$ & TST-6(100-120) & $820+/-70$ & -25.4 & $1161-1279 \mathrm{AD}$ & $1033-1296 \mathrm{AD}$ \\
\hline $38-4359$ & TST-6(120-140) & $950+/-70$ & -25.6 & $1018-1183$ AD & $978-1243$ AD \\
\hline $39-4362$ & TST-6(140-160) & $960+/-70$ & -24.2 & $1003-1162 \mathrm{AD}$ & $904-1222 \mathrm{AD}$ \\
\hline \multicolumn{6}{|c|}{ TST 9} \\
\hline $40-4593$ & TST-9 SE (40) & $330+/-70$ & -25.8 & $1467-1649 \mathrm{AD}$ & $1436-1945 \mathrm{AD}$ \\
\hline \multicolumn{6}{|c|}{ TST 10} \\
\hline $41-4595$ & TST-10 (20-40) & $700+/-70$ & -25.2 & $1268-1385 \mathrm{AD}$ & $1214-1404 \mathrm{AD}$ \\
\hline \multicolumn{6}{|c|}{ TST 12} \\
\hline $42-4596$ & TST-12 (40) & $720+/-70$ & -25.7 & $1259-1379 \mathrm{AD}$ & $1191-1399 \mathrm{AD}$ \\
\hline
\end{tabular}




\begin{tabular}{|c|c|c|c|c|c|}
\hline 43 - LLNL & TST-12(40-60) & $570+/-30$ & & $1280-1400 \mathrm{AD}$ & $1300-1430 \mathrm{AD}^{*} 3$ \\
\hline \multicolumn{6}{|c|}{$\begin{array}{l}\text { TST } 13 \\
\end{array}$} \\
\hline $44-4592$ & TST-13 (00-20) & $570+/-70$ & -25.6 & $1302-1426 \mathrm{AD}$ & $1286-1445 \mathrm{AD}$ \\
\hline $45-4594$ & TST-13 (20-40) & $830+/-70$ & -25.9 & $1160-1277 \mathrm{AD}$ & $1207-1294 \mathrm{AD}$ \\
\hline $46-4597$ & TST-13 (60) & $820+/-70$ & -25.2 & $1161-1279 \mathrm{AD}$ & $1033-1296 \mathrm{AD}$ \\
\hline \multicolumn{6}{|c|}{ TST 14} \\
\hline $47-4598$ & TST-14(20-40) & $870+/-70$ & -25.5 & $1040-1256 \mathrm{AD}$ & $1019-1283 \mathrm{AD}$ \\
\hline $48-4599$ & TST-14 (40-60) & $670+/-70$ & -25.7 & $1280-1393 \mathrm{AD}$ & $1223-1413 \mathrm{AD}$ \\
\hline \multicolumn{6}{|c|}{$\begin{array}{l}\text { TST } 15 \\
\end{array}$} \\
\hline $49-4600$ & TST-15 (20) & $660+/-70$ & -24.4 & $1282-1396 \mathrm{AD}$ & $1244-1418 \mathrm{AD}$ \\
\hline $50-4601$ & TST-15 (40) & $820+/-70$ & -25.9 & $1161-1279 \mathrm{AD}$ & $1033-1296 \mathrm{AD}$ \\
\hline \multicolumn{6}{|c|}{ TST 16} \\
\hline $51-4603$ & TST-16 (20) & $980+/-70$ & -25.1 & 997 - 1158 AD & $899-1216$ AD \\
\hline $52-4604$ & TST-16 (60) & $670+/-70$ & -25.8 & $1280-1393 \mathrm{AD}$ & $1223-1413 \mathrm{AD}$ \\
\hline \multicolumn{6}{|c|}{$\begin{array}{ll}\text { TST } 17 \\
\end{array}$} \\
\hline $53-4605$ & TST-17 (60) & $650+/-70$ & -26.1 & $1284-1398 \mathrm{AD}$ & $1258-1423 \mathrm{AD}$ \\
\hline \multicolumn{6}{|c|}{ Diekono } \\
\hline \multicolumn{6}{|c|}{ DIE 1} \\
\hline $54-4295$ & DIE-1(100-120) & $1380+/-70$ & -25.6 & $618-687 \mathrm{AD}$ & $541-777 \mathrm{AD}$ \\
\hline $55-4296$ & DIE-1(130) & $1430+/-70$ & -26 & $561-662 \mathrm{AD}$ & $440-759 \mathrm{AD}$ \\
\hline \multicolumn{6}{|c|}{ DIE 2} \\
\hline $56-4281$ & DIE-2(0-20) & $940+/-70$ & -25 & $1020-1205 \mathrm{AD}$ & $981-1256 \mathrm{AD}$ \\
\hline $57-4282$ & DIE-2 (20-40) & $930+/-70$ & -24.9 & $1021-1209 \mathrm{AD}$ & $983-1260 \mathrm{AD}$ \\
\hline $58-4283$ & DIE-2 (40-60) & $960+/-70$ & -25.2 & $1003-1162 \mathrm{AD}$ & $904-1222 \mathrm{AD}$ \\
\hline $59-4284$ & DIE-2 (60-80) & $960+/-70$ & -26.1 & $1003-1162 \mathrm{AD}$ & $904-1222 \mathrm{AD}$ \\
\hline $60-4293$ & DIE-2 (80-100) & $950+/-70$ & -25.4 & $1018-1183 \mathrm{AD}$ & $978-1243 \mathrm{AD}$ \\
\hline $61-4294$ & DIE-2(100-120) & $1020+/-70$ & -25.5 & $979-1148 \mathrm{AD}$ & $889-1185$ AD \\
\hline
\end{tabular}

Key: LLNL = Lawrence Livermore National Laboratory:

* Radiocarbon dates from iron objects processed by Dr. Andrea C. Cook at Lawrence Livermore National Laboratory, UC Berkeley.

*1 $=$ from an iron ring

*2 $=$ from a small iron spear

*3 = from a large iron spear

Mounds result from the piling up on the same spot of human occupation by-products. They include habitation features, craft installations, collapsed building material as well as discarded and abandoned material culture. They are therefore exclusively human-made and, depending on circumstances, can be either well preserved or significantly disturbed by erosion agencies. These formation processes that combine cultural (C-transforms) and natural (N-transforms) are well understood in general [2,3].

Habitation mounds dating from the Late Stone Age onwards are recorded in different parts of West Africa, from the Chadian basin to Mali and Guinea [4-18]. They consist either of a single small or large mound or of multiple mounds (mound-cluster). It has been suggested that mound-clusters may have derived from residential segregation, inhabited by different specialized more or less endogamic groups such as blacksmiths, potters, hunters, fishing folks, bards, etc. $[19,20]$. Distinct mounds are thus axiomatically considered to materialize residential segregation, and as such, are the signature of craft-specialization. The explanation is tautological. No excavation program was implemented to test the accuracy the hypothesis mentioned above. The testing procedure may have required an appropriate methodology, consisting at least of the probing of all the mounds part of the settlement complex under investigation, a precise and fine-grained chronology backing detailed analyses of material culture, architecture, and subsistence remains. It is then and only then that variation - or lack thereof - can be assigned to differences in social status. These principles have guided the field strategy implemented in the Mouhoun Bend Archaeological Project [21,22].

The Mouhoun River flows from the SW to NE, winds its course in a U-shape bend to follow a N-S direction (Figure 1). The study area located in the Sudano-sahelian zone is delimited in the north and northeast by the meandering river course. It measures $40 \mathrm{~km}$ 
East-West ( $3^{\circ} 11^{\prime}$ North $/ 3^{\circ} 32^{\prime}$ East) and 38km North-South $\left(12^{\circ}\right.$ $30^{\prime} / 12^{\circ} 45^{\prime}$ latitude North). The land, prone to cyclical droughts, is flat with elevation ranging from 294 to $249 \mathrm{~m}$ above sea level. The vegetation is characteristically a highly anthropic wooded savanna, with the protected shea-butter tree (Butyrospermum parkii) largely predominant, followed by different kinds of Acacia sp.

\section{The Study Area}

Seventeen settlements with two to seventeen mounds (Tomo in local Marka language) each were recorded in an area measuring $20 \mathrm{~km}$ east-west and $25 \mathrm{~km}$ north-south (Figure 1). Kirikongo and
Tora-Sira-Tomo/Gnambakouon-Sira-Tomo (TST/GST) are located at 280 to $284 \mathrm{~m}$ above sea level (asl). All the remaining settlements are found at elevation ranging from 280 to $260 \mathrm{~m}$ asl. There is an intriguing concentration of mound-clusters around Douroula in the central part of the surveyed area. The density of settlement is surprisingly low in the river valley if one considers that the region is prone to cyclical droughts. River blindness has plagued the whole Mouhoun River basin during the colonial period, and probably before. This may explain the avoidance of the river shores for direct settlement. There is no single permanent village on the river banks today. Instead, there are seasonal fishing camps set by non-local fishermen.

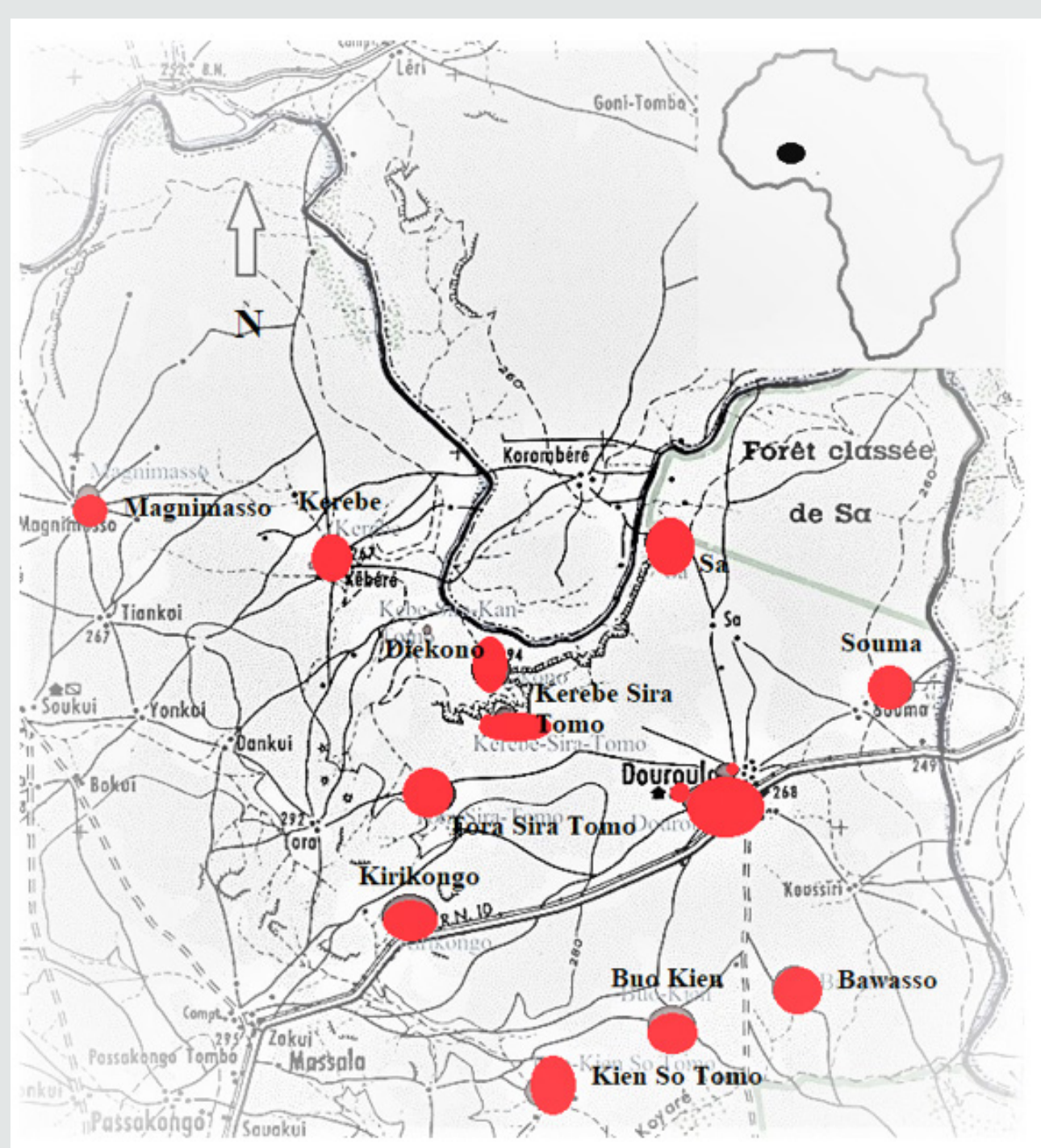

Figure 1: Distribution of archaeological sites in the Mouhoun Bend (Burkina Faso).

Three mound-clusters located in in different environments were selected for excavation: Diekono in the Mouhoun River floodplain, Kerebe-Sira-Tomo (KST) on the cliff delimiting the river valley, and Tora-Sira-Tomo (TST) and its satellite Gnambakouon-SiraTomo (GST) on the topographic rise in the central part of the study area. Each of the above mentioned sites is comprised of a number of mounds of different size and shape, iron-working workshops, and laterite quarries.

\section{The Dynamics of TST and KST Mound-clusters}

The long-term pattern of growth of inhabited space within a mound cannot be assessed with the field methodology implemented in this case, with one test unit per mound. A general time line of the settlement complex formation can nonetheless be reconstructed.

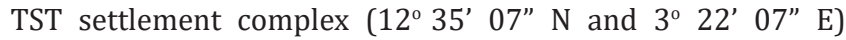
is located at $280 \mathrm{~m}$ asl. With 17 distinct mounds, it is the largest

Citation: Augustin FC Holl. The Dynamics of Mounds-Clusters in the Mouhoun Bend (Burkina Faso). J Anthro \& Archeo Sci 1(1)- 2019. 
settlement complex of the study area, spread over $900 \mathrm{~m}$ westeast and $500 \mathrm{~m}$ north-south, some 45 ha in total surface extent (Figure 2). TST-3, the largest mound stretched along the north edge measures $260 \mathrm{~m}$ west-east, and $120 \mathrm{~m}$ north-south. All 17 mounds were tested after three field seasons $(1997,1999$, and 2000). Five,
TST-1 (Iron smelting), TST-2 (quarry), TST-4 (cloth weaving and dyeing workshop), TST-9 (cemetery), and TST-17 (oil production workshop), are special purpose sites. The fourteen remaining ones were standard habitation mounds with varying occupation intensity.

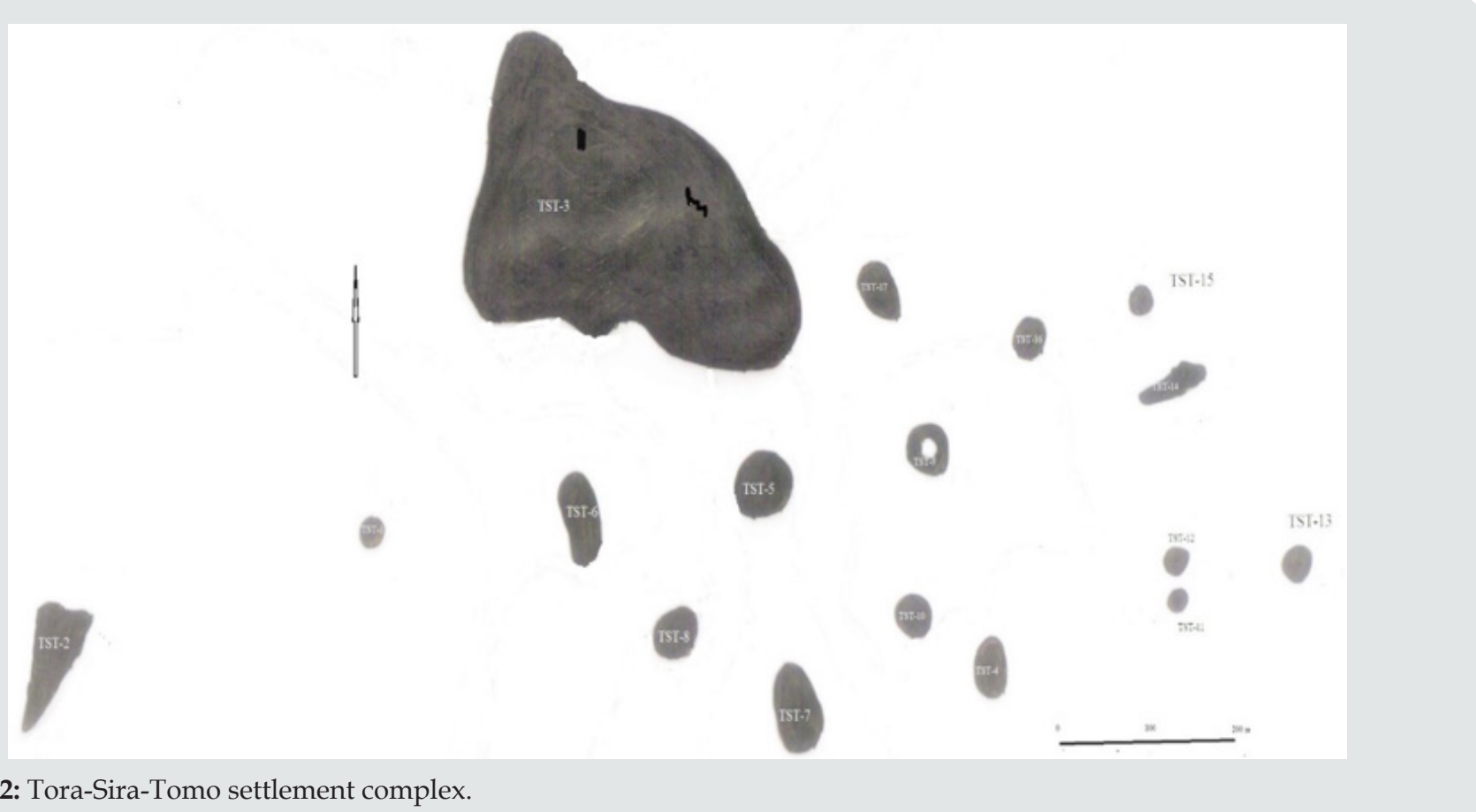

Figure 2: Tora-Sira-Tomo settlement complex.

KST settlement complex is located on the cliff top along the edge of the Mouhoun River valley (Figure 3). The complex consists of eleven more or less distinct mounds stretched on $350 \mathrm{~m}$ westeast and $600 \mathrm{~m}$ north-south. The cluster is made of three distinct sites categories: a quarry (KST-2) located at some $800 \mathrm{~m}$ east, iron-working stations both smelting and forging, and habitation mounds. Habitations mounds, clustered in the north, resulted in the formation of a large 15ha village site. All iron-working stations, arranged along a roughly ENE-WSW axis, are concentrated at 100 to $200 \mathrm{~m}$ along the south flank of the main habitation cluster. KST settlement complex was inhabited from the second half of the first millennium BC to the second half of the thirteenth-century AD, with an important 500 years occupation hiatus in the second half of the $1^{\text {st }}$ millennium AD. The development of TST and KST settlement complexes can be arranged in four successive phases, from the middle of the first millennium $\mathrm{BC}$ to the middle of the second millennium AD.

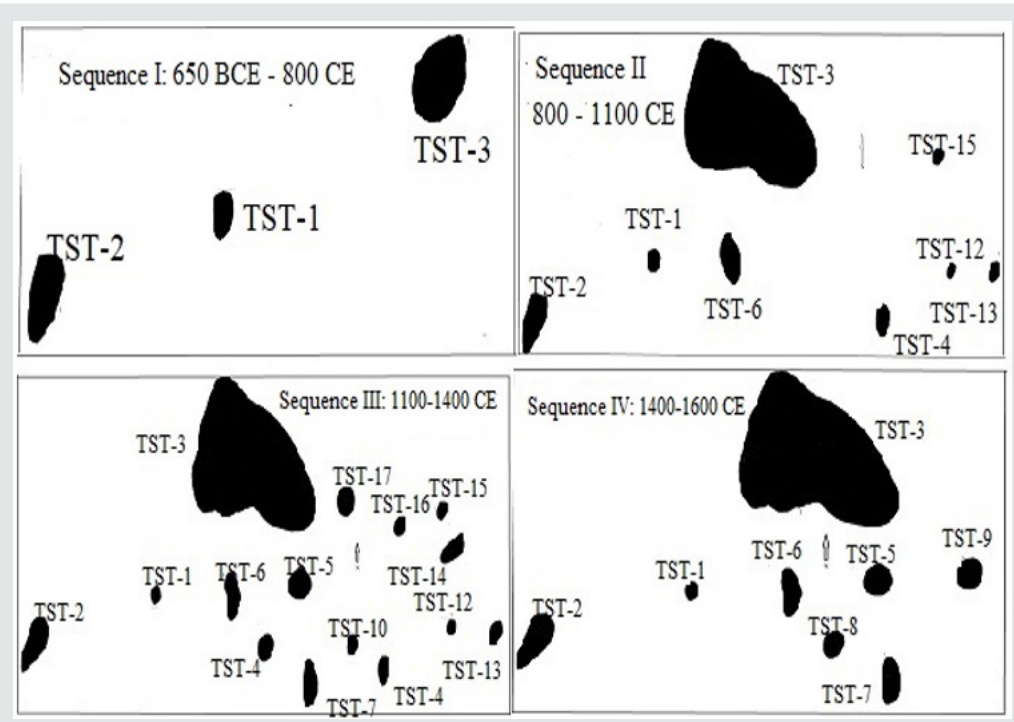

Figure 3: The evolution of TST settlement complex. 


\section{Phase I (650 BC-800 AD)}

At TST, the initial settlement phase (650 BC-800 AD) that started in the mid- $1^{\text {st }}$ millennium BC is documented at TST-1, TST-2, and TST-3-East (Figure 4, Table 2). The earliest occupations are found at
TST-1, an iron-smelting site dated to 650-395 BC (Figure 5), TST-2, the quarry site that provided raw material for house construction and iron production, and finally, the blacksmith workshop exposed at the bottom of TST-3-East probe.

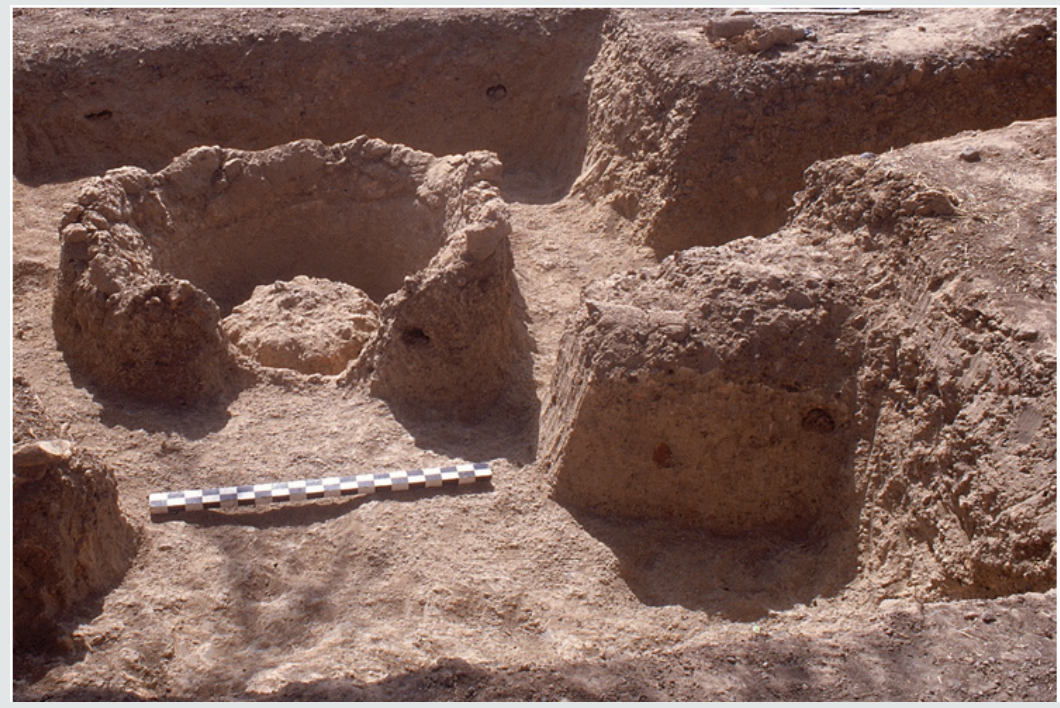

Figure 4: View of TST-1 iron smelting furnace.

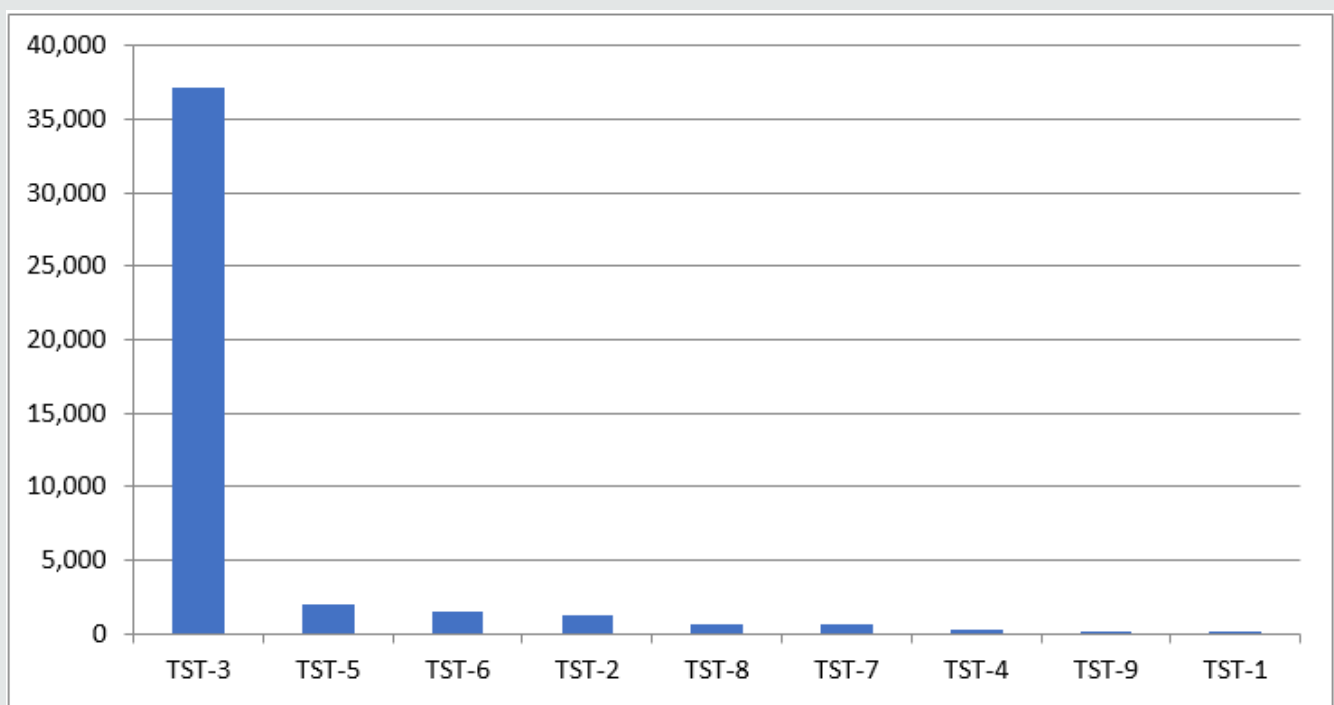

Figure 5: Differential mounds size in m2 during TST phase IV (1400 - $1650 \mathrm{CE})$.

Table 2: Tora-Sira-Tomo mound cluster at Phase I (650 BC - 800 AD).

\begin{tabular}{|c|c|c|c|c|c|}
\hline Mound & Size $\left(\mathbf{m}^{\mathbf{2}}\right)$ & Probe $\mathbf{( m}^{\mathbf{}} \mathbf{)}$ & Deposit $(\mathbf{m})$ & Number of Occupations & Nature \\
\hline TST-1 & 255 & 65 & $0.30-1.50$ & 2 & Iron-smelting site \\
\hline TST-2 & 1250 & 2 & $0.30-2.00$ & 1 & Quarry \\
\hline TST-3 & $? ? ?$ & 10.5 & 0.45 & Forge \\
\hline
\end{tabular}

KST settlement complex phase I dated to $350 \mathrm{BC}-150$ AD was shorter. It is documented in the west-central part of the complex, in KST-1A and KST-2 the quarry site (Figure 6). KST complex grew in two directions during its phase II dated to 250 - 550 AD. KST-
1B and KST-3 areas were settled. The mound was of an irregular potato- shape, oriented SW-NE. KST-2, the quarry site, was relied upon for the supply of iron ore and construction material during the whole existence of the settlement complex 


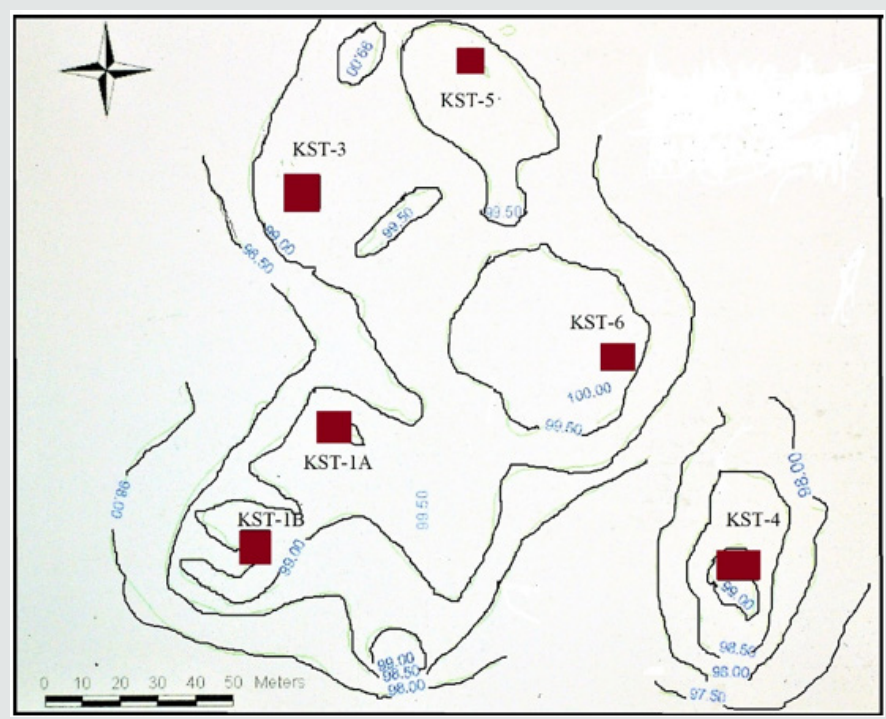

Figure 6: Kerebe-Sira-Tomo settlement complex.

\section{Phase II (800 - 1100 AD)}

TST Phase II (800-1100 CE) settlement with a total of 8 mounds, witnessed the foundation of 5 new sites. They were arranged in two sub-clusters of four sites each: TST-1, TST-2, TST- 3 , and TST- 6 in the west, and TST-4, TST-12, TST-13, and TST-15 in the east (Figure 4 , Table 3). The western sub-cluster consisted of two residential mounds: TST-3 and TST-6, and two special purpose sites: TST1(iron-smelting and ritual) and TST-2 (quarry). The eastern subcluster includes TST-13 and TST-15 residential sites, and TST-4 (weaving and cloth dyeing workshop) and TST-12 (a blacksmith workshop) special purpose sites (Holl 2014). KST complex was abandoned during all the second half of the $1^{\text {st }}$ millennium $A D$, from ca. 550 to $1000 \mathrm{AD}$.

Table 3: Tora-Sira-Tomo mound cluster in Phase II (800 - 1100 AD).

\begin{tabular}{|c|c|c|c|c|c|}
\hline Mound & Size $\mathbf{~}^{\mathbf{2}} \mathbf{)}$ & Probe $\left(\mathbf{m}^{\mathbf{}} \mathbf{)}\right.$ & Deposit $\mathbf{( m )}$ & Number of Occupations & Nature \\
\hline TST-1 & 255 & 65 & $0.30-1.50$ & 2 & Iron-smelting site \\
\hline TST-2 & 1,250 & 2 & $0.30-2.00$ & 2 & Quarry \\
\hline TST-3 & 37,200 & 35 & $0.40-0.85$ & 2 & Residential \\
\hline TST-4 & 345 & 72 & 0.8 & 2 & Weaving/Cloth dyeing workshop \\
\hline TST-6 & 1,500 & 9 & 2 & 2 & Residential \\
\hline TST-12 & 486 & 12 & 0.7 & 3 & Blacksmith workshop \\
\hline TST-13 & 1,963 & 33 & 0.7 & 2 & Residential \\
\hline TST-15 & 314 & 42 & 0.4 & Residential \\
\hline
\end{tabular}

\section{Phase III (1100 - 1400 AD)}

TST settlement complex reached its maximum extent during phase III (1100-1400 AD) with the addition of 7 new sites. All 15 mounds (Figure $4 \& 7$, Table 4 ) were located in the space delineated during phase I and II. The new additions are set in two patterns. TST-5, TST-7, TST-8, and TST-10 present a rectilinear arrangement of equidistant mounds at $100 \mathrm{~m}$ from one to the next. TST-5, TST7, and TST-8 residential mounds 'sits' on burials dug deep in the laterite crust in what may have been an earlier cemetery. TST-14, TST-16, and TST-17 are along the northeastern flank of the complex, at $100 \mathrm{~m}$ from one to the next, in a linear east-west arrangement. TST-14 and TST-16, were residential and TST-17 a karité oil production workshop.

Table 4: Tora-Sira-Tomo mound cluster in Phase III (1100 - 1400 AD).

\begin{tabular}{|c|c|c|c|c|c|}
\hline Mound & Size $\mathbf{( m}^{\mathbf{2}} \mathbf{P}$ & Probe $\mathbf{( m}^{\mathbf{2}} \mathbf{)}$ & Deposit $\mathbf{( m )}$ & Number of Occupations & Nature \\
\hline TST-1 & 255 & 65 & $0.30-1.50$ & 2 & Ritual site \\
\hline TST-2 & 1,250 & 2 & $0.30-2.00$ & 2 & Quarry site \\
\hline TST-3 & 37,200 & 35 & $0.40-0.85$ & 2 & Residential site \\
\hline TST-5 & 1,963 & 9 & 1.25 & 2 & Burial and Residential \\
\hline TST-4 & 345 & 72 & 0.8 & 2 & Cloth dyeing workshop \\
\hline TST-6 & 1,500 & 9 & 2 & Residential site \\
\hline
\end{tabular}




\begin{tabular}{|c|c|c|c|c|c|}
\hline TST-7 & 625 & 12 & 1.55 & 12 & Burial and Residential \\
\hline TST-8 & 706 & 9 & 1.25 & 1 & Burial and Residential \\
\hline TST-10 & 360 & 15 & 0.4 & 12 & Residential site \\
\hline TST-12 & 486 & 12 & 0.7 & 2 & Blacksmith workshop \\
\hline TST-13 & 1,963 & 33 & 0.7 & - & Residential site \\
\hline TST-14 & 1,400 & 12 & 0.6 & 2 & Residential site \\
\hline TST-15 & 314 & 42 & 0.4 & 1 & Residential site \\
\hline TST-16 & 300 & 12 & 0.6 & Residential site \\
\hline TST-17 & 520 & 12 & 0.6 & Oil production \\
workshop \\
\hline
\end{tabular}

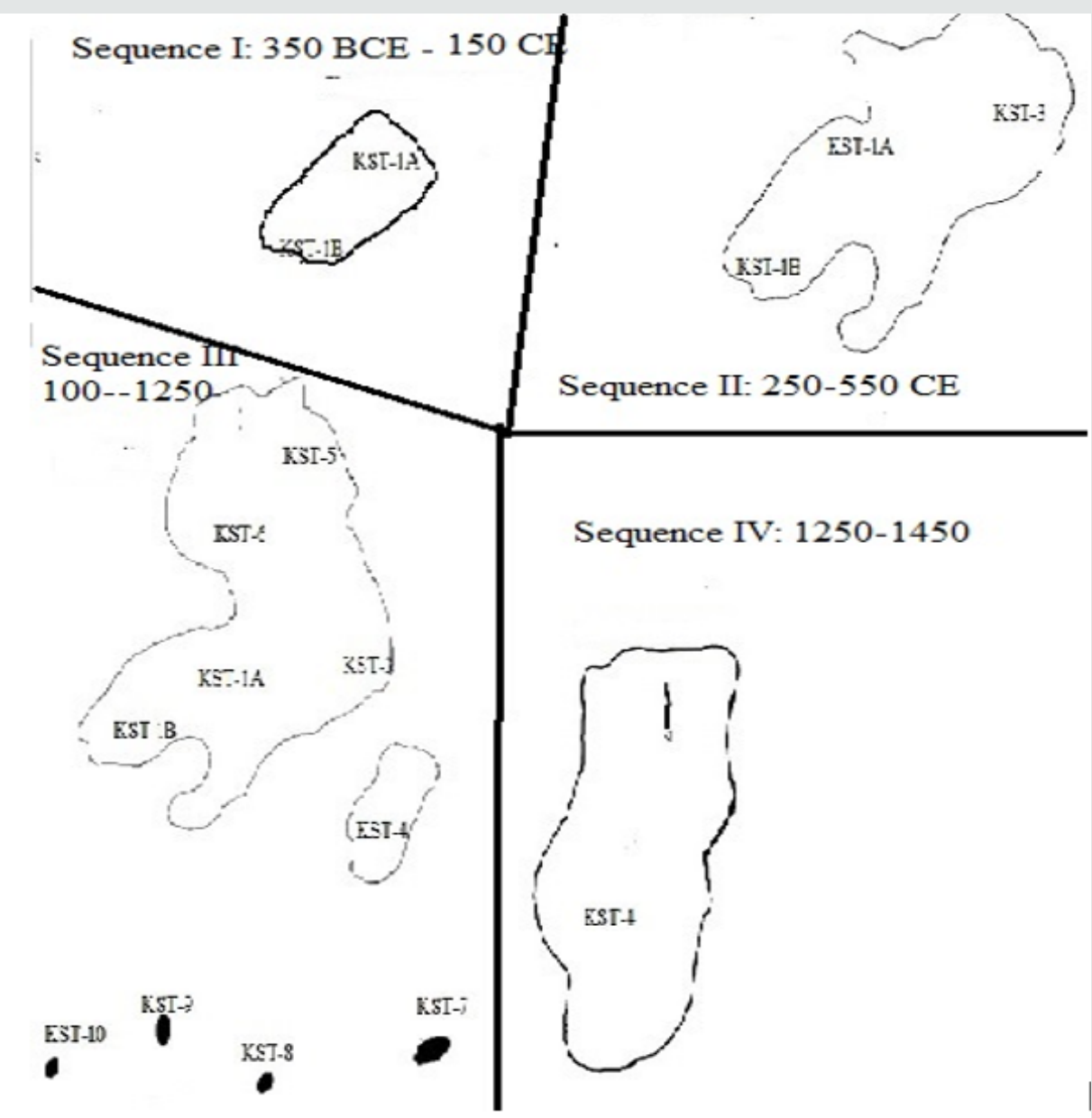

Figure 7: The evolution of KST settlement complex.

KST complex also witnessed an accelerated growth during Phase III (1000-1250). KST-IA and 1B, KST-2 (quarry site), KST-3, KST-4 (occupation I and II), KST-5, and KST-6 (Figure 6) were all inhabited and in use. Fire destroyed habitation units from KST-3 occupation I and KST-4 occupation II (Figure 8 \& 9), located along the southeast flank of the complex. There was also a significant intensification of iron-working, with the foundation of workshops devoted to iron-smelting, blow-pipes making, and blacksmithing along the south margins of the main village.

\section{Phase IV (1400 -1650 AD)}

TST settlement complex shrunk significantly during Phase IV (1400-1650 AD). The number of inhabited sites dropped from 15 to 9. The eastern part of the cluster was abandoned (Table 5, Figure 4). A new restricted access cemetery was founded at TST-9. TST-3, TST-4, TST-5, TST-6, TST-7, and TST-8, were residential. TST-1, TST2 , and TST-9, respectively iron-smelting site, quarry, and cemetery, were special purpose sites. In general, with the exception of TST8 set between TST-4 and TST-7 (Figure 4), the distance between neighboring mounds oscillates around $100 \mathrm{~m}$.

An identical phenomenon occurred at KST. The inhabited space also shrunk considerably during KST phase IV (1250-1450 AD) (Figure 6). Shallow occupation evidence is documented at KST-4 occupation III and IV, then used as a cemetery. 


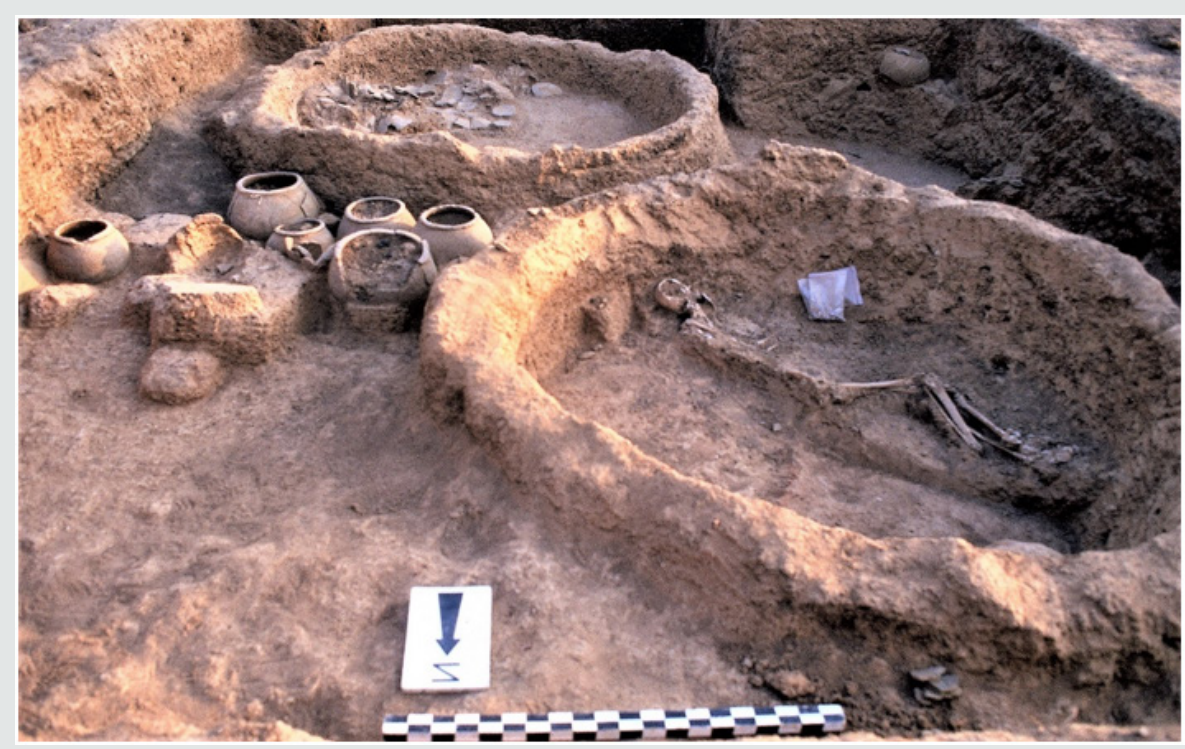

Figure 8: Partial view of KST phase III domestic unit.

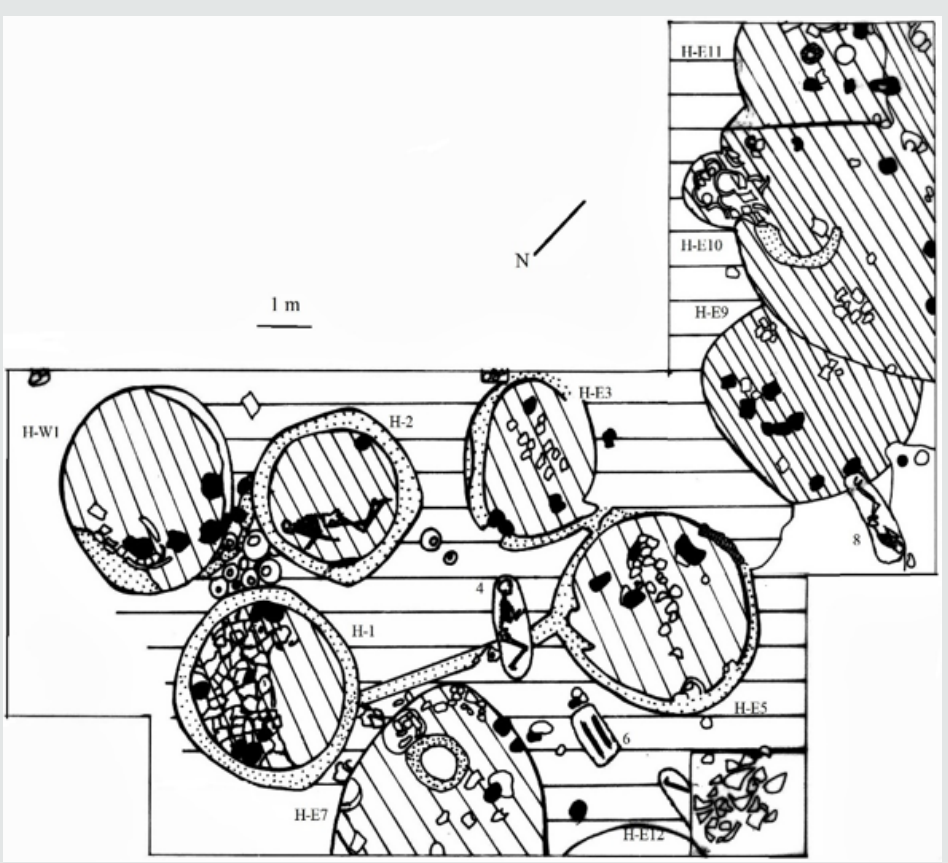

Figure 9: Habitation complexes from Phase III KST-4 .

Table 5: Tora-Sira-Tomo mound cluster in Phase IV (1400 - 1650 AD).

\begin{tabular}{|c|c|c|c|c|c|}
\hline Mound & Size $\mathbf{( m}^{\mathbf{}} \mathbf{)}$ & Probe $\mathbf{( m}^{\mathbf{}} \mathbf{)}$ & Deposit $\mathbf{( m )}$ & Number of Occupations & Nature \\
\hline TST-1 & 255 & 65 & $0.30-1.50$ & 2 & Ritual site \\
\hline TST-2 & 1,250 & 2 & $0.30-2.00$ & 6 & Quarry site \\
\hline TST-3 & 37,200 & 35 & $0.40-0.85$ & 2 & Residential site \\
\hline TST-4 & 345 & 72 & 0.8 & 2 & Cloth dyeing workshop \\
\hline TST-5 & 1,963 & 9 & 1.25 & 2 & Residential \\
\hline TST-6 & 1,500 & 9 & 2 & 2 & Residential site \\
\hline TST-7 & 625 & 12 & 1.55 & 2 & Burial and Residential and Residential \\
\hline TST-8 & 706 & 9 & 1.25 & 1 & Cemetery \\
\hline TST-9 & 225 & 113 & $0.30-1.20$ & & \\
\hline
\end{tabular}

Citation: Augustin FC Holl. The Dynamics of Mounds-Clusters in the Mouhoun Bend (Burkina Faso). J Anthro \& Archeo Sci 1(1)- 2019. 


\section{Variability of mounds clustering processes}

Data collected from the excavation of four settlement complexes point to the existence of two main mound-clustering strategies: a tight and a loose one. KST settlement complex that lasted from ca. $350 \mathrm{BC}$ to $1450 \mathrm{AD}$, with a half millennium occupation hiatus in the second half of the $1^{\text {st }}$ millennium $\mathrm{AD}$, features tight-clustering (Figure 7 \& 8). All the residential sites, with the exception of KST4 , are tightly packed in a 15 ha village. Iron-working sites located along the south periphery of the village display no habitation. Craft people and work crews were KST villagers who commuted to their workshops during the iron-production seasons.

TST-GST settlement complex with a total of 20 mounds features the loose-clustering strategy. The mound-sites, 17 for TST and 3 for GST are well demarcated, with each sub-set presenting a large dominant mound. Residential and special purpose sites are represented in varying combinations all along TST settlement complex occupation history.

Archaeological data indicate that flexible strategies were adopted by the different 'self-sustaining' autonomous ancient villages during the 2200 years' occupation of the Mouhoun bend. In KST, craft people resided in the village and commuted to their workshops located in the southern outskirts of the complex. In the TST alternative, with more or less inter-phase variations, craft people built their residence in distinct places and supplied local communities from their workshops. There is no fixed and permanent pattern of residential and occupational segregation in the analyzed archaeological record [21,22].

\section{Peer-village interaction}

The study area is relatively flat. The recorded settlement complexes are more or less evenly distributed in the landscape. In site-catchment analysis terms, each village is surrounded by rings of cultivated fields, fallow zones, and bush [23,24]. At their peak, during the first centuries of the $2^{\text {nd }}$ millennium $A D$, each of the recorded settlement complex was a large autonomous and selfsustaining village. Some, like KST and Kirikongo, were compact villages with a few outlying mounds and special purpose sites. Others, as was the case for TST - GST and Diekono, were spread out with a multiplicity of distinct mounds.

There are no significant wealth differences. Grave-goods and burial offerings are too marginal to be significant. Some individuals, male, female, children, and infants, were nonetheless buried in "restricted access" cemeteries while others were buried in their compounds. This differential treatment points to subtle variations in social status without detectable and/or durable material correlates. The accelerated growth at the beginning of the $2^{\text {nd }}$ millennium $\mathrm{AD}$ initiated a scramble for land, villages rivalry, violence, and wars.

\section{Fire: accidents or wars?}

Burnt houses were recorded in some of the excavated mounds. It is the case at TST-3-West in occupation I and II, dated to 10001150 AD. Domestic installations belonging to two successive occupations were totally burnt down. KST complex also present two instances of burnt domestic installations dated to $1050-1380$ AD: one at KST-3 occupation I and the other at KST-4 occupation II. In the latter case, a whole household complex with its food supply was destroyed by fire (Figure 9). Similar cases of burnt installations dated to 1300-1450 AD were recorded at Kirikongo, Mound III, level 8 and Mound IV, level 7 [8]. These events took place during a period of accelerated growth that triggered violent confrontations.

\section{War, Violence and surgery}

There is no direct one to one correlation but the unrest indicated by burnt houses is partly corroborated by traumatic injuries found on some of the deceased. Two male and female adult individuals buried in the same context at TST-7 appears to have been victims of the same violent encounter. One, a 35-50 years old adult female presents 4 well healed cranial fractures on the occipital, frontal, and left parietal. The other, an impressive $1.95 \mathrm{~m}$ tall $45+$ years old male presents two distinct episodes of trauma. He recovered from previous blows indicated by a well healed circular defect on the occipital. He has multiple trephinations with no signs of healing on the right, left parietals and frontal, showing that the second series of blows was fatal. Remarkably, both adults present similar blows patterns: they were hit on the frontal, occipital, left and right parietals, as if the aggressors were well trained fighters [25-27]. The surgery may have taken place after a violent raid. Finally, a 9-11 years old pre-adolescent, individual 18 from phase IV TST9 cemetery, presents multiple peri-mortem depressed cranial features made by a sharp object, that was very likely the cause of death [26].

The recorded evidence on traumatic injuries is dated to phase III (1000-1200 AD) and IV (1250-1500 AD) when the area witnessed a significant growth acceleration followed by the onset of devolution. There are convincing evidence of conflict and intervillage warfare during the first half of the second millennium AD. The nature and characteristics of the kind of warfare that may have developed in the area during this phase of accelerated growth are difficult to decipher. The tactics involved may have consisted of surprise raiding and counter-raiding with the aim of seizing supplies and host [27-37].

\section{Conclusion}

Each village had its autonomous system of government, with horizontally differentiated groups. These mixed farming communities included a number of craft specialists, potters, ironsmelters and blacksmiths, masons, cloths weavers and dyers, 
karite-oil producers, as well as part-time warriors, and healers (surgeons). The Mouhoun Bend peer-villages were autonomous and self-sustaining but not autarkic. A general compatibility of "worldviews" is suggested by the strong coherence of mortuary practices. Despite variations, pottery decoration techniques and syntax suggest a shared cultural universe. The mound-dwellers of the Mouhoun Bend developed an original socio-political system that, for approximately two centuries, from 1200 to $1400 \mathrm{AD}$, existed on the periphery of the powerful expansionist Mali Empire.

\section{Acknowledgments}

The Mouhoun Bend Archaeological Project (Burkina Faso 19972000) was funded by a CNRS grant in 1997, a National Geographic Society Research Grant \# 6378-98 in 1998, and a Faculty Startup Fund from the University of California, San Diego in 2000. The author is grateful of the support of these institutions and also wish to thank the CNRST - Centre National de la Recherche Scientifique et Technique - for the research permit and the Archaeology Laboratory of Ouagadougou University for logistical support. Students from the University of Paris X Nanterre, the University of Ouagadougou, and the University of California, San Diego participated with enthusiasm to the field programs.

\section{References}

1. Hely C, Lezine AM, APD Contributors (2004) Holocene changes in African vegetation: Trade off between climate and water availability. Climate of the Past 10: 681-686.

2. Holl A (1987) Mound Formation Processes and Societal Transformations: A Case Study from the Perichadian Plain. Journal of Anthropological Archaeology 6(2): 122-158.

3. Schiffer MB (2002) Formation Processes of the Archaeological Record Utah University Press, Salt Lake City, USA.

4. Albert KD, Hallier M, Kahlheber S, Pelzer C (2000) Montee et Abandon des collines d'occupation de l'Age de Fer au Nord du Burkina Faso. In Kulturentwicklung und Sprachgeschichte im Naturraum Westafrikanische Savanne. Berichte des Sonderforshungs-bereichs 268, Band 14, Frankfurt am Main, pp. 335-351.

5. Bedaux RMA (1972) Tellem, Reconnaissance Archeologique d'une culture de l'Ouest Africain au Moyen Age, Recherches Architectoniques. Journal de la Societe des Africanistes 42(2): 105-185.

6. Bedaux RMA (1980) The geographic distribution of footed bowls in the Upper and Middle Niger Region. In: Swartz BK, Dumett RA (Eds.), West African Culture Dynamics. Mouton Publishers, The hague, Paris pp. 247258.

7. Bedaux R, MacDonald K, Person A, Polet J, Sanogo K, et al. (2001) The Dia Archaeological Project: rescuing cultural heritage in the inland Niger delta (Mali). Antiquity 75(290): 837-848.

8. Dueppen SA (2008) Re-Inventing Equality: The archaeology of Kirikongo, Burkina Faso. PhD Dissertation, The University of Michigan, Ann Arbor, Michigan, USA.

9. Filipowiak W (1979) Etudes archeologiques sur la Capitale Medievale du Mali. Scezecinic Museum Narodowe, Poland.

10. Holl AFC (2002) The Land of Houlouf: Genesis of a Chadic Polity ca 1900 BC - AD 1800. University of Michigan Museum of Anthropology, Ann Arbor, Michigan, USA.

11. Holl AFC (2004) Holocene Saharans: An Anthropological Perspective. Continuum, London/USA.
12. Holl AFC (2006) West African Early Towns: Archaeology of Households in urban landscapes. University of Michigan Museum of Anthropology, Ann Arbor, Michigan, USA.

13. Polet J (2004) L'emergence de la ville en Afrique Sub-saharienne. In: Bazzana A, Bocoum H (Eds.), Du Nord au Sud du Sahara: Cinquante Ans d’Archeologie Francaise. Editions Sepia, Paris, pp. 249-259.

14. McIntosh RJ, McIntosh SK (1980) Prehistoric Investigations at Jenne, Mali: a study in the development of urbanism in the Sahel British Archaeological Report, Oxford, England.

15. McIntosh RJ (2005) Ancient Middle Niger: Urbanism and the SelfOrganizing Landscape. Cambridge; Cambridge University Press. 112(1): 316-317.

16. Raimbault M, Sanogo K (1991) Recherches Archeologiques au Mali. ACCT - Karthala, Paris, France.

17. Togola $\mathrm{T}$ (1993) Archaeological Investigations of Iron Age sites in the Mema Region, Mali (West Africa). PhD Dissertation. University Microfilms International, Rice University, Ann Arbor, Michigan, USA.

18. Togola T (1996) Iron Age Occupation in the Méma region, Mali. African Archaeological Review 13(2): 91-110.

19. McIntosh RJ (1999) Peoples of the Middle Niger. Blackwell, Oxford, USA.

20. McIntosh SK (1999) Modeling political organization in large scale settlement clusters: A case study from the Inland Niger Delta. In: McIntosh SK (Ed.), Beyond Chiefdoms: Pathways to Complexity in Africa. pp. Cambridge University Press, Cambridge, England, pp. 66-79.

21. Holl AFC (2014) Archaeology of West African Mounds Clusters. Monographs in African Archaeology, British Archaeological Reports International Series, Oxford, USA.

22. Holl AFC, Lassina K (2000) Settlement patterns, food production and craft specialization in the Mouhoun Bend (NW Burkina Faso): preliminary results of the MOBAP 1997-1999 field seasons. West African Journal of Archaeology 30(1): 69-107.

23. Chisholm M (1979) Rural Settlement and Land Use: An Essay in Location. Hutchinson, London.

24. Higgs ES, Vita-Finzi C (1970) Prehistoric Economy of the Mount Carmel Area of Palestine: Site-catchment Analysis. Proceedings of the Prehistoric Society 36: 1-37.

25. Gjerdrum T, Holl AFC, Maes KC, Walker PL (2002) West African trephination: Skeletal evidence from Tora Sira Tomo, Burkina Faso. Poster presented at the $14^{\text {th }}$ Biennial European Members Meeting of the Paleopathology Association, Aug. 28-31, Coimbra, Portugal.

26. Maes KC, Irish JD, Holl AFC, Walker PL, Armelagos GJ (2014) Preliminary analysis of dental morphology and identity of an early iron producing population in the Mouhoun, Burkina Faso. Poster presented at the $73^{\text {rd }}$ Annual Meetings of the American Assocation of Physical Anthropologists, April 14-17, 2004.

27. Crubezy E, Bruzek J, Guilaine J, Cunha E, Rouge D, et al. (2001) The Antiquity of cranial surgery in Europe and the Mediterranean basin. Compte Rendus de l'Academie des Sciences: Sciences de la Terre et des Planetes 332(6): 417-423.

28. Holl A (1993) Transition from Late Stone Age to Iron Age in the SudanoSahelian zone: A case study from the Perichadian Plain. In: Shaw T, Sinclair V, Andah B, Okpoko A (Eds.), The Archaeology of Africa: Food, Metals and Towns. London, Routledge, pp. 330-343.

29. Holl AFC (1994) The cemetery of Houlouf in Northern Cameroon (A.D. 1500 -1600): Fragments of a past social system. African Archaeological Review 12: 133-170.

30. Holl AFC (2009a) West African early metallurgies: New Evidence and old orthodoxy. Journal of World Prehistory 22(4): 415 -438.

31. Holl AFC (2009b) Iron Metallurgy in West Africa: An Early Iron Smelting Site in the Mouhoun Bend, Burkina Faso. In: Magnavita S, Kote L, Breunig 
P, Ide OA (Eds.), Crossroads/Carrefour Sahel: Cultural and Technologica Developments in the first millennium BC/AD West Africa. Journal of African Archaeology Monographs Series, Frankfurt, 2: 59-68.

32. Lebeuf JP (1969) Carte Archeologique des Abords du Lac Tchad. Editions du Centre National de la Recherche Scientifique, Paris, France.

33. McIntosh SK (1995) Excavations at Jenne-Jeno, Hambarketolo, and Kaniana (Inland Niger Delta, Mali), the 1981 field season. University of California Press, Berkeley, USA.

34. McIntosh RJ, McIntosh SK (1984) The Early City in West Africa: Toward an Understanding. The African Archaeological Review 2: 73-98.
35. McIntosh RJ, McIntosh SK (1993) Cities without citadels: Understanding urban origins along the Middle Niger. In: Shaw T, Sinclair P, Andah BW Okpoko A (Eds.), The Archaeology of Africa: Food, Metals, and Towns. London and New York; Routledge, pp. 622-641.

36. Pelzer C, Magnavita-Santos S (2000) La Necropole de Kissi et ses implications historiquea. In Kulturentwicklung und Sprachgeschichte im Naturraum Westafrikanische Savanne. Berichte des Sonderforshungsbereichs, Frankfurt am Main, 268. Pp. 367-373.

37. Schiffer MB (1983) Toward the identification of formation processes. American Antiquity 48(4): 675-705.
(C) This work is licensed under Creative

To Submit Your Article Click Here:

Submit Article

DOI: $10.32474 / J A A S .2019 .01 .000101$

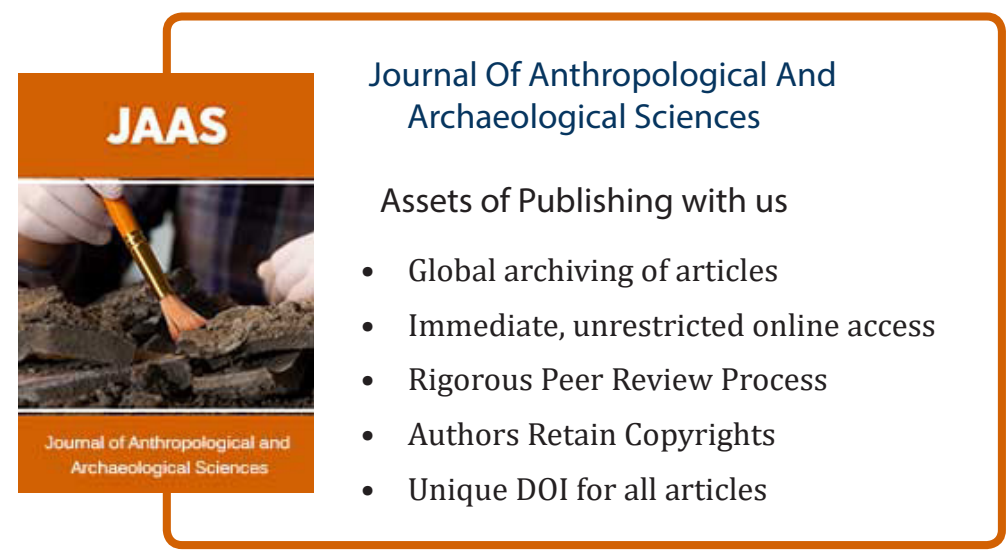

Citation: Augustin FC Holl. The Dynamics of Mounds-Clusters in the Mouhoun Bend (Burkina Faso). J Anthro \& Archeo Sci 1(1)- 2019. 